in S.typhi, which was completely inhibited by a 1 in 1,000 concentration, almost completely by 1 in 2,000 , and partially by 1 in 4,000, an elongation of the cells, which was enormous at these two latter dilutions, could still be detected at 1 in 32,000 . Vib. cholerce, which was inhibited only slightly at 1 in 1,000 , growing as immense swollen filaments, showed appreciable lengthening up to 1 in 8,000 . Similarly with the Salmonella group, Bact. coli and other Gramnegative rods, which often showed grotesque giantforms due to the autolytic swelling and frequent bursting of elongated cells.

The changes are similar to and at least as great as those figured by Ainley Walker and Murray ${ }^{2}$ in their experiments on the effect of methyl-violet and other dyes on the typhoid-coli group of bacteria.

The growth of Brucella melitensis and abortus is not inhibited by penicillin at 1 in 1,000 , the strongest solution tested; nor is there any enlargement of the cells. But a vacuolation of the majority of them was seen in both species at 1 in a few thousands, and in $B r$. abortus this effect could be decreasingly traced right down to 1 in 300,000 . It does not, however, seem likely that such a minor disturbance can be of great importance.

Gram-positive organisms, which are in general a good deal more sensitive to penicillin than the Gramnegative rods, show similar phenomena. For example, $C l$. welchii, which was completely inhibited at 1 in 60,000 , showed considerable filament-formation right up to 1 in a million and a half. In Bac. anthracis the corresponding figures were about 30,000 for total inhibition and 300,000 for lengthening.

With the Staphylococci the morphological change takes the form of spherical enlargement of the cell and imperfect fission, easily detectable at dilutions four to eight times higher than the completely inhibitory dilution, which, with a very small inoculum, may be as high as $1 / 800,000$.

Streptococcus pyogenes, an extremely sensitive species, showed great swelling of the cells, incomplete fission with formation of large spinoles, and increased length of chains. This occurred at dilutions at least four times higher than the completely inhibiting dilution, which was 400,000 . The growth was deposited, leaving a clear supernatant fluid. Several appearances were seen in Str. viridans at 1 in 50,000, though growth was completely inhibited at only 1 in 4,000 .

I have not been able to see any morphological effect on the Meningococcus, though it is inhibited by penicillin at 1 in 50,000 .

An observation by $R$. Tunnicliff ${ }^{3}$ on the action of sulphanilamide on Streptococcus viridans probably points to a similar phenomenon. She found that the drug causes the coceus to form more and longer chains and to grow in granular form in fluid media. This change she considers to be in the direction of roughness, and adds that it "appears to make the Streptococci more phagocytable".

Thus it seems that toxic dyes, the atoxic penicillin and probably sulphanilamide cause similar morphological changes at incompletely inhibitory concentrations, and that the changes are mainly due to a failure of fission. Growth proceeds, but division and separation do not follow in due course. Many cells then fall victim to autolysis.

If the bacteria, as Tunnicliff suggests in the case of sulphanilamide, are thereby reduced in virulence, the chemotherapeutic agent can be expected to exert some action in vivo at concentrations much lower than those needed for complete inhibition of growth.

It should be noted that penicillin is not yet a pure substance, so that the figures given must be taken with considerable reserve.

A. D. Gardner.

Sir William Dunn School of Pathology, University of Oxford. Dec. 10 .

${ }^{1}$ Lancet, $226(1940)$.

${ }^{2}$ Brit. Med. J., 2, 16 (1904).

${ }^{3}$ J. Inf. Dis., 64, 59 (1939).

\section{Para-Amino Benzoic Acid as a Bacterial Growth Factor}

The mode of action of sulphanilamide has been the subject of much recent work. Possibly the most precise contribution has been Woods's discovery of the anti-sulphanilamide effect of $p$-amino benzoie acid ('p.a.b.'). In a discussion of this work, Fildes ${ }^{1}$ has suggested that 'p.a.b.' might be considered an essential metabolite for bacteria. It is now inferred that sulphanilamide inactivates an essential coenzymic grouping of the susceptible organism ${ }^{1,2}$, and in view of Woods's work, this grouping is most probably 'p.a.b.'. Before this hypothesis of sulphanilamide action can be widely accepted it remains to be proved that 'p.a.b.' is essential for the growth of organisms inhibited by the drug.

Previous work by Brown et al. ${ }^{4}$ on the growth requirements of the butyl alcohol - acetone organism, Clostridium acetobutylicum, has shown that thiamin, riboflavin, tryptophane, nicotinic acid, pimelic acid, pantothenic acid, alanine and uracil, are unable to stimulate growth in synthetic media. More recently Weizmann ${ }^{5}$ (1939) has stated that biotin was essential for the growth of this organism.

In our earlier work on the isolation of the growth factor for $\mathrm{Cl}$. acetobutylicum a yeast concentrate was prepared which supported growth of the organisms in a concentration of $2 \times 10^{3} \mu \mathrm{gm}$. per ml. of a basal medium of the following composition: asparagine 0.1 per cent, glucose 2.0 per cent, $\mathrm{KH}_{2} \mathrm{PO}_{4} 0.5$ per cent, $\mathrm{K}_{2} \mathrm{HPO}_{4} 0.5$ per cent, $\mathrm{MgSO}_{4} 0^{\circ} 2$ per cent, $\mathrm{NaCl} 0 \cdot 1$ per cent, $\mathrm{FeSO}_{4} \cdot 7 \mathrm{H}_{2} \mathrm{O} 0.01$ per cent, $\mathrm{MnSO}_{4}$. $4 \mathrm{H}_{2} \mathrm{O} \quad 0.01$ per cent, in distilled water.

Thirty kgm. of brewer's yeast (wet) yielded $750 \mathrm{mgm}$. of yeast concentrate by a procedure too lengthy to describe in this communication. An ether extract of this concentrate was evaporated, benzoylated, and the product (recrystallized five times from alcohol), was identified as $p$-benzoyl-amino benzoic acid, m.p. $277^{\circ} \mathrm{C}$, yield $2 \mathrm{mgm}$. In Table $\mathrm{l}$ are recorded the results of experiments condensed from the study of nine species of $\mathrm{Cl}$. acetobutylicum, of which seven were isolated in this laboratory and two were obtained from the American Type Cultures Collection Nos. 862 and 4259. Growth has only been recorded as positive when the test medium gave growth in five successive subcultures.

From Table 1 the following conelusions may be drawn :

(1) $p$-amino benzoic acid and its derivatives act as growth factors for $\mathrm{Cl}$. acetobutylicum.

(2) $p$-amino benzoic acid can be recovered from a yeast concentrate factor as the benzoyl derivative.

(3) Removal of $p$-amino benzoic acid from the yeast concentrate removes its growth factor activity. 
TABLE 1.

GROWTH FACTORS FOR $C l$. acetobutylicum AND REIATED SUBSTANCES.

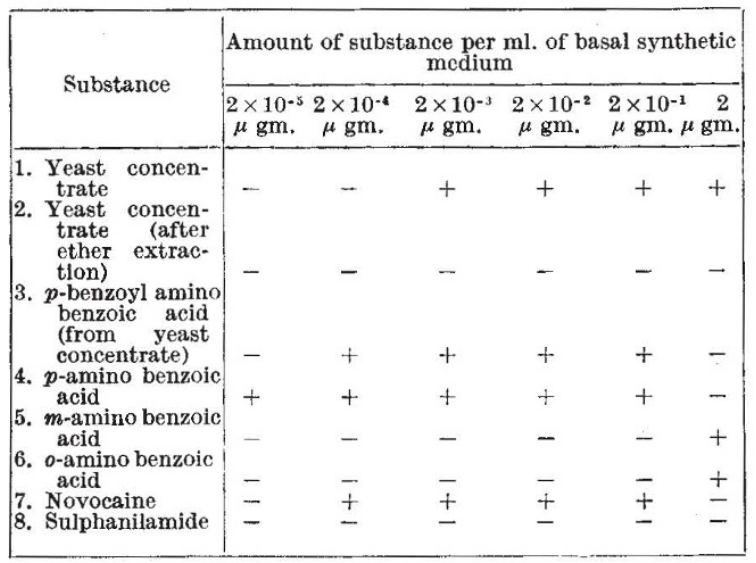

Growth +, no growth -

A comparison of these results with the antisulphanilamide tests of Woods reveals a remarkable correlation. In this work the growth factor activity is : $p$-amino benzoic acid $6.8 \times 16^{-8} M$., novocaine $1.2 \times 10^{-8} M$., ortho and meta amino benzoic acid probably inactive. In regard to Weizmann's statement, it is presumed that his biotin, which stimulated growth, contained $p$-amino benzoic acid.

The bacteriostatic action of sulphanilamide on growth was determined by subculturing the organisms in the basal medium containing varying quantities of 'p.a.b.' and constant amounts of sulphanilamide. The results recorded in Table 2 confirm Woods's findings ${ }^{6}$ on the anti-sulphanilamide action of 'p.a.b.' They also illustrate how it is possible to titrate the two antagonists using growth as the end point.

TABLE 2.

TItration of $p$-AMINo BENZOIC ACID AgaINST SUlphaNILAMIDE.

\begin{tabular}{|c|c|c|c|c|c|c|}
\hline \multirow{2}{*}{$\begin{array}{l}\text { Concen- } \\
\text { tration of } \\
\text { sulphanil- } \\
\text { amide }\end{array}$} & \multicolumn{5}{|c|}{$\begin{array}{c}\text { Amount of } p \text {-amino benzoic acid per } \mathrm{ml} \text {. } \\
\text { of basal medium }\end{array}$} & \multirow{2}{*}{$\begin{array}{l}\text { Molecular } \\
\text { ratio } \\
\text { 'p.a.b.': } \\
\text { sulphanil- } \\
\text { amide }\end{array}$} \\
\hline & $\begin{array}{l}5 \times 10^{-3} \\
\mu \mathrm{gm}\end{array}$ & $\begin{array}{l}1 \times 10^{-3} \\
\mu \mathrm{gm}\end{array}$ & $\begin{array}{l}2 \times 10^{-3} \\
\mu \mathrm{gm}\end{array}$ & $\begin{array}{l}3 \times 10^{-3} \\
\mu \mathrm{gm}\end{array}$ & $\begin{array}{l}4 \times 10^{-3} \\
\mu \mathrm{gm}\end{array}$ & \\
\hline$\frac{M}{1,650}$ & - & - & - & - & - & 23,000 \\
\hline$\frac{M}{3,300}$ & - & - & + & + & + & 23,000 \\
\hline$\frac{M}{6,600}$ & - & + & + & + & + & 23,000 \\
\hline
\end{tabular}

Growth + , no growth -

On the basis of the above figures one molecule of 'p.a.b.'antagonizes 23,000 molecules of sulphanilamide. This tremendous disproportion between these two antagonistic reagents makes it difficult to conceive how the growth activator 'p.a.b.' can overcome the effect of the growth inhibitor (sulphanilamide) if the two molecules are destined towards the same receptor site on the organism. The chances of the activator making first contact seem fairly remote when considered from a physico-chemical point of view.

University of Melbourne.

SydNey D. RubBo. Oct. 22 .

'Fildes, Lancet, 1, 955 (1940).

' Stamp, Lancet, 11, 10 (1939).

3 Green, Brit. J. Exp. Path., 21, 38 (1940).

- Brown, Wood and Werkman, J. Bact., 38, 631 (1939).

- Weizmann, Biochem. J., 33, 1376 (1939).

s Woods, Brit. J. Exp. Path, 21, 74 (1940).

\section{Chromosome Diminution in a Plant}

THE genus Sorghum consists of two groups. Eu-Sorghum includes the tetraploid millet species and an octoploid fodder species ${ }^{1}$. Para-Sorghum includes only diploid species $(n=5)$ which are not cultivated. One of these is $S$. purpureo-sericeum, from the Sudan, in which I have described plants with varying numbers of extra chromosomes. These chromosomes I supposed to be inert ${ }^{2}$.

I now find from meiosis in the pollen mother cell that, amongst a wild 1931 collection of seeds given me by Mr. C. E. Hubbard of Kew, 40 out of 100 had these extra chromosomes (Table 1).

TABLE 1.

Plants With $B$ CHRoMosomes In Sorghum purpureo-sericeum.

$\begin{array}{lllllllll}\text { No. of } B \text { 's } & 0 & 1 & 2 & 3 & 4 & 5 & 6 & \text { Total }\end{array}$ $\begin{array}{lllllllll}\text { Total plants } & 60 & 12 & 20 & 5 & 1 & 1 & 1 & 100\end{array}$ $\begin{array}{lllllllll}\text { Tested in roots } & - & 8 & 7 & 2 & 1 & 1 & 1 & 20\end{array}$

Thus there appears to be the same kind of distribution of extra $B$ chromosomes in the natural population of this species as occurs in certain cultivated varieties of maize ${ }^{3}$. Again as in maize, these $B$ chromosomes do not pair at meiosis with the five ordinary members of the complement. They have, therefore, lost all effective relationship with the active chromosomes, alongside which they must have maintained a separate existence for a great time.

That these chromosomes are in some respects active, and disadvantageously active, is shown by the proportion of healthy pollen (from 500 grains each) in plants having different numbers of $B$ 's (Table 2). Their long maintenance in the species therefore demands that they have certain com. pensating advantages for the plant.

TABLE 2.

Effect of $B$ 's on Average Pollen fertulity.

No. of $B^{\prime}$

No. of Plants

$\begin{array}{cccc}0 & 1 & 2 \\ 6 & 3 & 5\end{array}$

Good pollen

$93 \cdot 6 \% \quad 83 \cdot 6 \%$

$83 \% \quad 11 \cdot 5 \%$

From mitosis in the root-tips, however, a new and remarkable property of these $B$ chromosomes appears. Twenty plants having $B$ 's in the pollen mother cells were examined. None had $B$ 's in the roots. All had the ordinary chromosome complement of 10 (second line, Table 1).

Re-examination of the flower-tissues of these plants showed the presence of $B$ 's at metaphase of mitosis. The resting cells also frequently contained small extra nuclei, which had doubtless arisen from lagging $B$ 's. Since these chromosomes are maintained in the tissue, it seems that the extra nuclei must rejoin their companions during mitosis in the flower parts. In the early growth of the roots, on the other hand, they must be lost.

Now irregularities (attributed to a deficient centromere) have often been found in the mitotic movements of extra chromosomes, but never before has a regular loss of such chromosomes been recorded in a particular tissue of a plant. The case at once recalls the well-known diminution of chromosomes in Ascaris and, still more forcibly, the exclusion of certain 'sex-limited' chromosomes from the somatic line in Sciara".

The further study of these highly controlled chromosomes is therefore likely to throw light on 